\title{
$\begin{array}{r}\text { WAGENINGEN } \\ \hline\end{array}$
}

\section{Cell-type-specific promoter identification using enhancer trap lines}

\author{
Radoeva, T., Saiga, S., \& Weijers, D.
}

This is a "Post-Print" accepted manuscript, which has been published in "None"

This version is distributed under a non-commercial no derivatives Creative Commons (c) (1) $\Theta \Theta$ reproduction in any medium, provided the original work is properly cited and not used for commercial purposes. Further, the restriction applies that if you remix, transform, or build upon the material, you may not distribute the modified material.

Please cite this publication as follows:

Radoeva, T., Saiga, S., \& Weijers, D. (2018). Cell-type-specific promoter identification using enhancer trap lines. In Methods in Molecular Biology (Vol. 1830, pp. 127-139). (Methods in Molecular Biology; Vol. 1830). Humana Press Inc.. DOI: 10.1007/978-1-4939-8657-6_8

You can download the published version at:

https://doi.org/10.1007/978-1-4939-8657-6_8 


\title{
Cell-type-specific promoter identification using enhancer trap lines
}

\author{
Tatyana Radoeva, Shunsuke Saiga and Dolf Weijers*
}

Laboratory of Biochemistry, Wageningen University \& Research, Stippeneng 4, 6708WE

Wageningen, the Netherlands

* Corresponding author: dolf.weijers@wur.nl

RUNNING HEAD: Promoter identification using enhancer trap lines 


\begin{abstract}
Many developmental processes involve transitions between different cell identities as cells differentiate or undergo reprogramming. Cell identity specifications are generally associated with the activation and suppression of specific sets of genes mediated by transcription factors. Therefore, transcriptional reporters, such as promoters of cell-type-specific genes are broadly used as cell identity markers in developmental biology. In Arabidopsis (Arabidopsis thaliana), a collection of GAL4/UAS enhancer trap lines is an established standard for inferring cell identity. However, only a few of these enhancer trap lines have been molecularly characterized, which limits their potential. Here, we describe an approach for a detailed characterization of expression and mapping of T-DNA insert location of GAL4/UAS enhancer trap lines. Additionally, we demonstrate how the acquired information can be further used for the generation of novel celltype-specific promoters as well as for genotyping of enhancer trap lines.
\end{abstract}

Key words: Arabidopsis, Cell-type-specific promoters, Expression analysis, Enhancer trap lines, TAIL-PCR, Insert location 


\section{Introduction}

Multicellular organisms have developed a myriad of different cell types and cell identity determination is thus very important. A cell type is generally outlined by morphology and unique cell-type-specific gene expression program mainly mediated by transcription factors. Therefore, transcriptional reporters, such as gene promoter-reporter fusions or enhancer trap lines are regularly used as cell identity markers [1-3]. However, the amount of well-established marker genes in the plant community is limited and does not cover all the different cell types, which urges a need for robust cell identity markers. Identification of novel genes with cell-type-specific expression patterns is also proven to be extremely useful in studying cell reprogramming, where differential gene expression is usually the first mark that a cell has attained a different developmental fate, and needs to be systematically followed [4-6].

In this chapter, we discuss in detail an approach for molecular characterization of Arabidopsis (Arabidopsis thaliana) GAL4-dependent Upstream Activation Sequence (GAL4/UAS) enhancer trap lines for the identification of novel cell-type-specific promoters. These GAL4/UAS enhancer trap lines provide a valuable set of markers in which specific cell-types are fluorescently tagged and can easily be visualized [7]. These lines were generated by random insertion of modified GAL4-VP16 gene along with the GAL4-dependent UAS-driven green fluorescent protein (GFP; mGFP5ER) in the Arabidopsis genome. Since the expression of the GAL4-VP16 gene relies on the presence and activity of genomic enhancer sequences adjacent to minimal promoter elements, a variety of different expression patterns can be generated, depending on the genomic insertion site of the transgene [7]. In addition, cell-type-specific GAL4-VP16 expression allows local gene misexpression [7-9]. A separate line carrying a gene of interest placed under the control of GAL4-dependent UAS can be maintained silently in the absence of GAL4. A 
genetic cross between this line and any GAL4-containing line will trigger specific expression of the gene of interest in the GFP-marked domain $[8,10,6]$.

Recently, a set of commonly used GAL4/UAS enhancer trap lines was characterized in detail [11]. Their expression pattern was systematically documented and extended to the embryo, since during embryogenesis the basic body plan is established, encompassing all the distinctive tissue types [12]. Furthermore, the molecular characterization of these enhancer trap lines was completed by mapping of their insert location and the information obtained was applied for generating novel cell-types specific markers.

Here, we provide a complete protocol for detailed characterization of GAL4/UAS enhancer trap lines. Expression pattern analysis by confocal microscopy, identification of T-DNA insert location by thermal asymmetric interlaced (TAIL-) PCR, generating cell-type-specific promoters and genotyping of GAL4/UAS enhancer trap lines will be discussed. 


\section{Materials}

\subsection{Expression Analysis of GAL4/UAS enhancer trap lines by Confocal Microscopy}

1. Transgenic GAL4/UAS enhancer trap lines carrying a green fluorescent protein (GFP) or transgenic lines carrying a promoter of a gene of interest fused to a fluorescent protein such as GFP.

2. Stereomicroscope.

3. Tweezers (e.g., Dumont Swissmade 0108-5-PO)

4. Needle (e.g., Microlance; 30.6 x 25 mm)

5. Microscope slides.

6. Microscope coverslips $24 \times 50 \mathrm{~mm}$.

7. Double-sided adhesive tape.

8. Mounting solution: $4 \%[\mathrm{w} / \mathrm{v}]$ paraformaldehyde (PFA) in phosphate-buffered saline (PBS) buffer (pH 8.0), 5\% [v/v] glycerol, 0.4\% [v/v] dimethyl sulfoxide (DMSO), and 1.5\% [v/v] SCRI Renaissance Stain 2200 (SR2200; Renaissance Chemicals, Selby, UK). The Renaissance stain binds to the cell wall and it is used as a counterstaining. For imaging of roots $10 \mu \mathrm{g} / \mathrm{ml}$ propidium iodide (PI) solution is used as counterstaining.

9. Leica SP5-II System (HyD detector; see Note 1).

\subsection{Identification of T-DNA insert location}

\subsubsection{Genomic DNA extraction from GAL4/UAS enhancer trap lines}


1. CTAB extraction buffer: $1 \%[\mathrm{w} / \mathrm{v}]$ cetyltrimethylammonium bromide (CTAB), 100 mM Tris- $\mathrm{HCl}(\mathrm{pH} 7.5), 10 \mathrm{mM}$ EDTA (pH 8.0), $0.7 \mathrm{M} \mathrm{NaCl}$, water (see Note 2).

2. Chloroform.

3. Isopropanol.

4. $70 \%$ ethanol.

5. Sterile Milli-Q water.

6. $4 \mathrm{~mm}$ steel beads.

7. $1.5 \mathrm{ml} 8$ strip tubes (e.g. LABO) or $2 \mathrm{ml}$ microcentrifuge tubes.

8. Milling machine (e.g., MM400; Retch GmbH, Germany).

9. Liquid nitrogen.

10. UV-Vis spectrophotometer (e.g. NanoDrop 2000 Thermo Scientific).

\subsubsection{Identification of T-DNA insert location by TAIL-PCR}

1. Genomic DNA from GAL4/UAS enhancer trap lines.

2. T-DNA specific primers (SP): $0.4 \mu \mathrm{M} \mathrm{SP} 1$ for primary reaction, $0.4 \mu \mathrm{M} \mathrm{SP} 2$ for secondary reaction, $1.2 \mu \mathrm{M} \mathrm{SP} 3$ for tertiary reaction and $5 \mu \mathrm{M} \mathrm{SP} 3$ for sequencing PCR product (see Note 3 ).

3. Arbitrary degenerate primers (AD): $4 \mu \mathrm{M}$ for primary and secondary reaction and 8 $\mu \mathrm{M}$ for tertiary reaction (see Note 4).

4. Taq DNA Polymerase (either commercial or home-made).

5. 10x PCR Buffer

6. $10 \mathrm{mM}$ dNTPs mixture of dATP, dTTP, dCTP and dGTP.

7. $1 \%$ Agarose gel. 
8. Gel extraction kit (e.g., GeneJET gel extraction kit, Thermo Scientific).

9. Thermocycler (e.g., Bio-Rad T100).

10. PCR tubes.

11. Tabletop microcentrifuge (e.g., Beckman Coulter Microfuge 18 Centrifuge).

\subsection{Generating cell-type-specific promoters by Ligation-Independent Cloning}

1. Plant expression Ligation-Independent Cloning (LIC) vector pPLV04v2 [13,14]

2. Up to $4 \mathrm{~kb}$-fragments upstream of the ATG of the identified gene of interest were amplified and cloned into the above mentioned LIC vector for expression analysis harboring 3 copies of GFP (see Note 5).

\subsection{Genotyping of GAL4/UAS enhancer trap lines}

1. Genomic DNA from homo- and heterozygous GAL4/UAS enhancer trap plants, and C24 wild-type plants.

2. Taq DNA Polymerase (either commercial or home-made).

3. 10x PCR Buffer

4. $10 \mathrm{mM}$ dNTPs mixture of dATP, dTTP, dCTP and dGTP.

5. Thermocycler (e.g., Bio-Rad T100).

6. PCR tubes.

7. $1 \%$ Agarose gel.

8. Tabletop microcentrifuge (e.g., Beckman Coulter Microfuge 18 Centrifuge).

\section{Methods}




\subsection{Expression Analysis of GAL4/UAS enhancer trap lines by Confocal Microscopy}

1. For imaging embryos: isolate ovules from collected siliques and place them in a drop ( $50 \mu \mathrm{l})$ of mounting Renaissance R2200 solution on a slide. After application of the coverslip, squeeze the embryos out of the ovules using the tip of a pencil (see Note 6).

2. For imaging roots: incubate 5-day-old seedlings in $10 \mu \mathrm{g} / \mathrm{ml}$ PI solution for 1 to 2 minutes and place them subsequently in a drop of water on a slide. Alternatively, directly place the seedlings in a drop of PI solution on a slide.

3. Samples can be observed using confocal microscope. The settings that can be used to visualize SCRI Renaissance R2200 and GFP are excitation at $405 \mathrm{~nm}$ and $488 \mathrm{~nm}$ and detection between $430-470 \mathrm{~nm}$ and $500-535 \mathrm{~nm}$, respectively. PI can be visualized by excitation at $488 \mathrm{~nm}$ and detection between $630-700 \mathrm{~nm}$.

\subsection{Identification of T-DNA insert location}

\subsubsection{Genomic DNA extraction from GAL4/UAS enhancer trap lines}

1. Before sampling, put a $4 \mathrm{~mm}$ steal bead inside each tube and place the tubes on ice.

2. Harvest the plant material (about 2-3 small leaves or 10-20 seedlings) directly into the tubes, which already contain a $4 \mathrm{~mm}$ steal bead (see Note 7).

3. Freeze the collected plant material in liquid nitrogen. Grind it using milling machine. To obtain a fine powder shake at frequency 30/s for 30 seconds, repeat if necessary.

4. Add $200 \mu \mathrm{l} \mathrm{CTAB}$ extraction buffer and briefly vortex to homogenize the mixture.

5. Incubate at $37^{\circ} \mathrm{C}$ for at least 30 minutes.

6. Add $200 \mu \mathrm{l}$ chloroform and vortex the mixture vigorously. 
7. Centrifuge for 10 minutes at $12000 \mathrm{x} g$ at room temperature (see Note 8).

8. Carefully transfer about $150 \mu$ of the upper aqueous phase into new tubes (see Note 9).

9. Add $200 \mu \mathrm{l}$ isopropanol to precipitate the DNA, mix gently by inverting the tubes 5-6 times and incubate for 5 minutes at room temperature.

10. Centrifuge for 10 minutes at $12000 \mathrm{x}$. Discard the supernatant carefully.

11. Add $200 \mu 170 \%$ ethanol to wash the DNA pellet.

12. Centrifuge for 10 minutes at $12000 \mathrm{x} g$. Discard the ethanol carefully as above to prevent dropping the DNA pellet.

13. Air dry the DNA pellet for at least 30 minutes (usually at $37^{\circ} \mathrm{C}$ ).

14. To dissolve the DNA, add 50-100 $\mu$ l sterile Milli-Q water and leave overnight at $4^{\circ} \mathrm{C}$.

15. Measure the concentration and purity of the DNA using UV-Vis spectrophotometer.

\subsubsection{Identification of T-DNA insert location by TAIL-PCR}

TAIL-PCR is a simple, but highly efficient method for identification and recovery of unknown genomic sequences flanking known sequences (or insertion sites; see Fig. 1a). The TAIL-PCR exploits two sets of primers: nested sequence-specific (SP) and arbitrary degenerate (AD) primers. Key characteristics of the two primer sets are the different length and different melting temperatures (also known as thermal asymmetry) [15]. The nested specific primers are designed complementary to the known sequence (usually in the proximity of one of the T-DNA borders), pointing outwards to the flanking unknown sequence (see Fig. 1a). These primers are 
long and anneal at high temperatures. On the other hand, the arbitrary degenerate primers are shorter and have lower melting temperatures. This difference in melting temperatures between the two sets of primers allows for a thermal control of the relative amplification efficiencies of specific and unspecific products [15]. Usually the TAIL-PCR consists of three subsequent rounds, ensuring further specificity (see Fig. 1b).

a

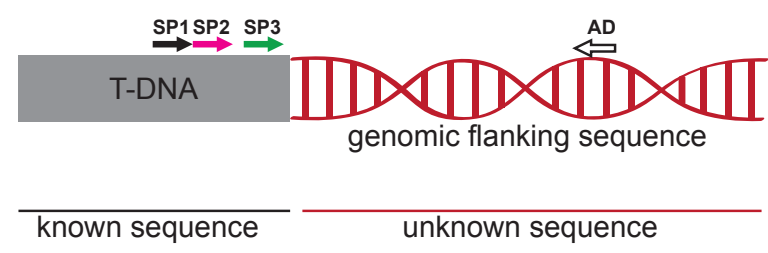

b

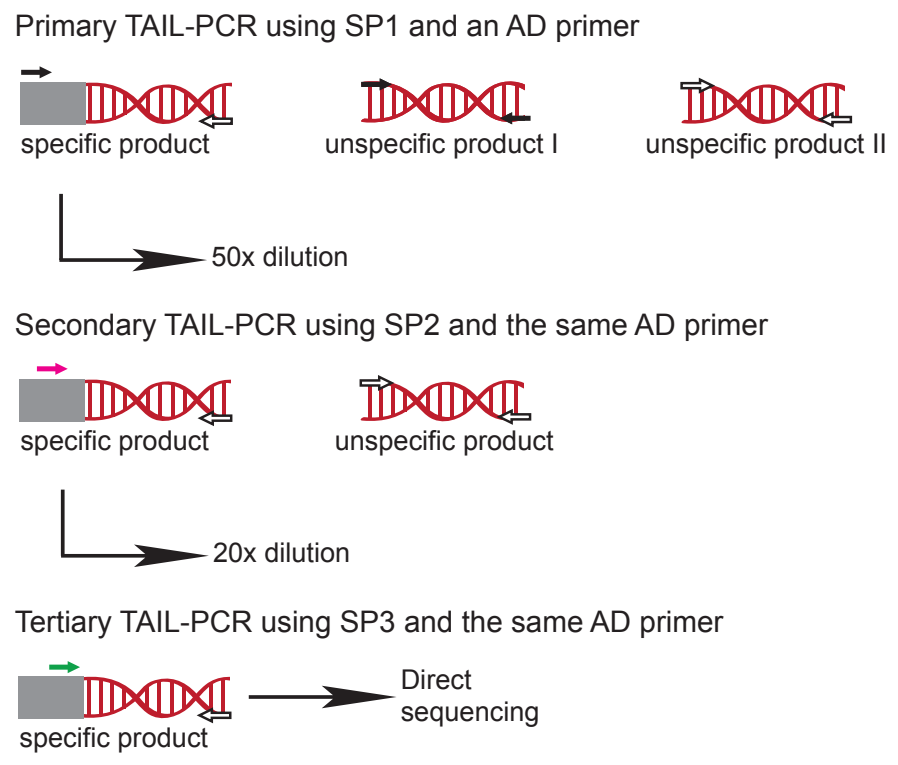

Figure 1

The primary TAIL-PCR round starts with five high stringency cycles (with high annealing temperature), allowing only the specific primer to bind and generating specific single-stranded product. Thereafter, one low stringency cycle (with low annealing temperature) creates one or 
more AD primer-specific target sites for the subsequent TAIL-cycling. The TAIL-cycling consists of fifteen super cycles and each super cycle involves swapping two high stringency cycles with one that has low stringency. The latter permits preferential amplification of specific product(s) over unspecific ones [15-17]. In the end of the primary TAIL-PCR round, three types of products are present: two types of unspecific products primed by either only the nested specific primer or only by the AD primers, and a specific product (see Fig. 1b).

To increase the amount of the desired specific product and at the same time to get rid of the contaminating unspecific products, a secondary TAIL-PCR round is performed followed by a tertiary TAIL-PCR round, exploiting another set of nested specific primers (see Fig. 1b). Dilution of the primary and the secondary PCR products preceding the subsequent reaction in combination with limited number of high stringency cycles minimizes the amplification of the undesired unspecific products. Finally, confirmation of product specificity is facilitated by visual assessment on agarose gel, where secondary and tertiary PCR products are loaded close to each other (see Fig. 2a). Here we demonstrate the use of this method to identify the T-DNA insert locations in GAL4/UAS enhancer trap lines.

1. Prepare and thaw the 10x PCR buffer, $10 \mathrm{mM}$ dNTP mixture and the $20 \mu \mathrm{M}$ SP1 and $\mathrm{AD}$ primers. Keep all solutions on ice.

2. Perform the primary TAIL-PCR reaction in a total volume of $20 \mu$ l. Prepare master mix of the primary reaction for each of the AD primers (see Table 1, Note 10 and 11). Mix well before distributing into the PCR tubes.

3. Add $16 \mu \mathrm{l}$ of master mix to each PCR tube. Add $4 \mu \mathrm{l}$ of different DNA samples. Briefly mix and spin down before placing the tubes into the thermocycler. 
4. Thermocycling conditions used for the primary reaction are shown in Table 2.

5. After completion, dilute each product from the primary reaction 50x ( $1 \mu 1$ product in $49 \mu \mathrm{l}$ Milli-Q water) and use $1 \mu \mathrm{l}$ of that dilution as a template for the secondary reaction (see Note 12).

6. Perform the secondary reaction in a total volume of $20 \mu \mathrm{l}$. Prepare master mix of the secondary reaction for each of the AD primers (see Table 1). Mix well before distributing into the PCR tubes.

7. Add $19 \mu$ of master mix to each PCR tube. Add $1 \mu$ of diluted product from the primary reaction. Briefly mix and spin down before placing the tubes into the thermocycler.

8. Thermocycling conditions used for the secondary reaction are shown in Table 2.

9. After completion, dilute each product from the secondary reaction $20 \mathrm{x}(1 \mu \mathrm{l}$ in 19 $\mu \mathrm{l}$ Milli-Q water) and use $0.8 \mu \mathrm{l}$ of that dilution as a template for the tertiary reaction.

10. Perform the tertiary reaction in a total volume of $40 \mu \mathrm{l}$. Prepare master mix of the tertiary reaction for each of the $\mathrm{AD}$ primers (see Table 1). Mix well before distributing into the PCR tubes.

11. Add $39.2 \mu \mathrm{l}$ of master mix to each PCR tube. Add $0.8 \mu \mathrm{l}$ of diluted product from the secondary reaction. Briefly mix and spin down before placing the tubes into the thermocycler.

12. For the tertiary reaction use the same thermocycling conditions as for the secondary reaction (see Table 2). 
13. After completion, run the secondary and the tertiary PCR products on $0.8-1 \%$ agarose gel. The specific products are verified by the anticipated size shift of the secondary and tertiary PCR products. Target products are expected to be smaller than the secondary products (see Fig. 2a).

14. Cut the specific gel bands and isolate the DNA using gel extraction kit by following the manufacturer's protocol.

15. Sequence the purified DNA using primer SP3 or another insertion-specific primer as the sequencing primer.

16. To identify the T-DNA insertion site, do a database search using the Basic Local Alignment Search Tool (BLAST) through the NCBI website (https://blast.ncbi.nlm.nih.gov/Blast.cgi; see Fig. 2b)

a

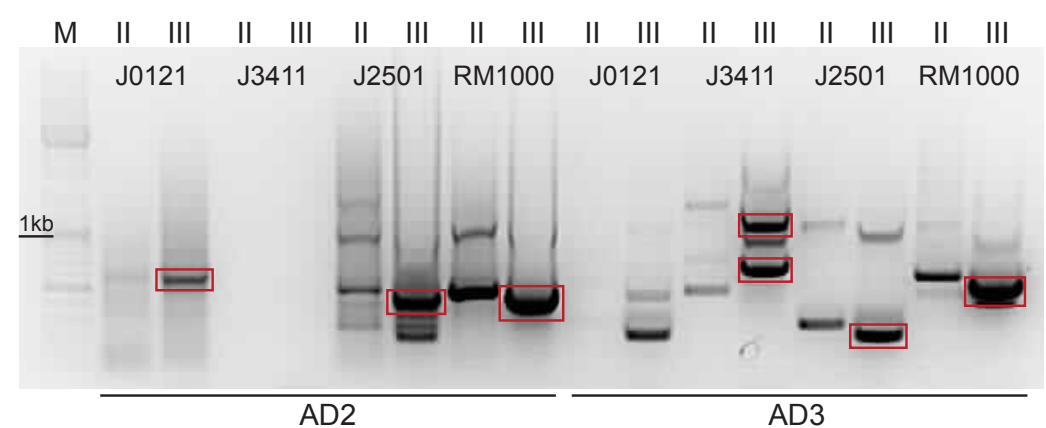

b

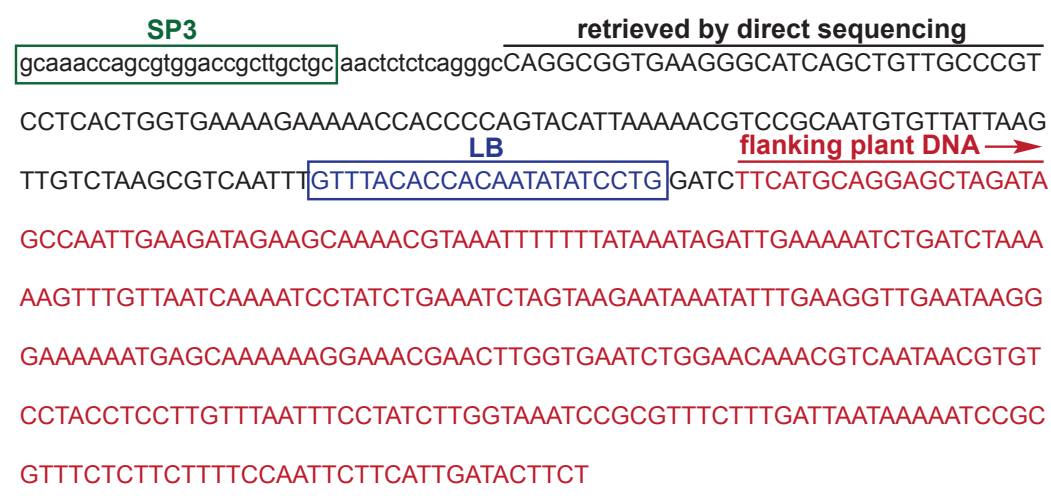

Figure 2 


\subsection{Genotyping of GAL4/UAS enhancer trap lines}

1. Design one pair of specific primers, which binds to the identified by TAIL-PCR genomic sequence flanking the left and the right border of the T-DNA (see Fig. 3; see Note 13).

2. Extract genomic DNA from the GAL4/UAS enhancer trap lines and C24 wild type plants.

3. Prepare and thaw the 10x PCR buffer, $10 \mathrm{mM}$ dNTP mixture and the $20 \mu \mathrm{M}$ primers. Keep all solutions on ice.

4. Do the PCR reaction in a total volume of $20 \mu 1$. Prepare a master mix for each of the primer combinations. Each reaction contains the following: $1 \mu \mathrm{l}$ of genomic DNA (added at the end), $2 \mu \mathrm{l}$ of 10x PCR buffer, $0.4 \mu \mathrm{l}$ of $10 \mathrm{mM}$ dNTPs, $0.5 \mu \mathrm{l}$ of $20 \mu \mathrm{M}$ forward primer, $0.5 \mu \mathrm{l}$ of $20 \mu \mathrm{M}$ reverse primer, $0.1 \mu \mathrm{l}$ Taq Polymerase and up to 20 $\mu 1$ Milli-Q water.

5. Add $19 \mu \mathrm{l}$ of master mix to each PCR tube. Add $1 \mu \mathrm{l}$ of genomic DNA. Briefly mix and spin down before placing the tubes into the thermocycler.

6. Thermocycling conditions used for the PCR reaction are as follows: $95^{\circ} \mathrm{C}$ for 2 minutes; 35 cycles of $95^{\circ} \mathrm{C}$ for $30 \mathrm{~s}, 60-65^{\circ} \mathrm{C}$ for $30 \mathrm{~s}, 72^{\circ} \mathrm{C}$ for $30 \mathrm{~s} ; 72^{\circ} \mathrm{C}$ for 5 minutes and $12^{\circ} \mathrm{C} \infty$.

7. After completion, run the PCR product on a $1 \%$ agarose gel. 


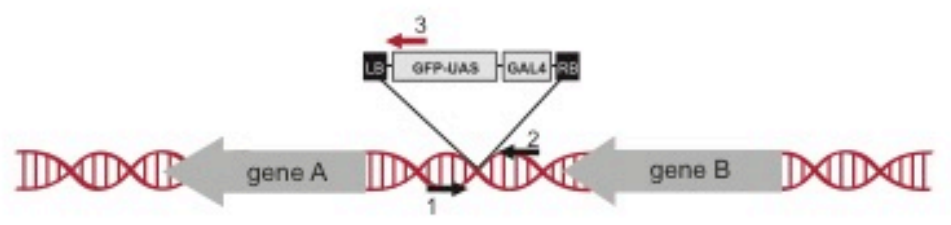

Figure 3

\section{Notes}

1. Imaging can be performed on any alternative microscope that allows detection and visualization of GFP and SCRI Renaissance Stain 2200 fluorescence.

2. To prepare $100 \mathrm{ml}$ of $1 \%$ CTAB extraction buffer, add $10 \mathrm{ml}$ of $1 \mathrm{M}$ Tris- $\mathrm{HCl}(\mathrm{pH} 7.5)$, $14 \mathrm{ml} 5 \mathrm{M} \mathrm{NaCl}$ (make sure that the $\mathrm{NaCl}$ concentration is $5 \mathrm{M}$, if lower concentration is used, DNA will precipitate in the buffer), $2 \mathrm{ml} 0.5 \mathrm{M}$ EDTA ( $\mathrm{pH} \mathrm{8.0)}$ and water up to $100 \mathrm{ml}$ final volume. Store the solution at room temperature. Just prior to use, add $1 \mathrm{~g}$ CTAB.

3. Specific primers (SP) are nested primers, designed in a close proximity of the left border of the GAL4/UAS vector used for T-DNA tagging. The three primers SP1, SP2 and SP3 have melting temperatures $\left(T_{m s}\right)$ of $61.1^{\circ} \mathrm{C}, 61.1^{\circ} \mathrm{C}$ and $65.8^{\circ} \mathrm{C}$, respectively. SP2 and SP3 are designed 30 bp away from each other in order to enable determination of product specificity by size comparison. The following specific primers were used for mapping of the T-DNA insertion sites:

SP1: 5'-GGAACAACACTCAACCCTATCTCGGG-3';

SP2: 5'-GGGATTTTGCCGATTTCGGAACCACC-3'; SP3: 5'-GCAAACCAGCGTGGACCGCTTGCTGC-3'. 
4. Arbitrary degenerate primers (AD) are shorter (15- or 16-mers) than nested specific primers and have $T_{m}$ of about $45^{\circ} \mathrm{C}$. In our lab, we use the following AD primers, previously designed by Liu et al., 1995 [17].

AD2: 5'-NGTCGA(G/C)(A/T)GANA(A/T)GAA-3' (128-fold degeneracy);

AD3: 5'-(A/T)GTGNAG(A/T)ANCANAGA-3' (256-fold degeneracy).

5. Constructs were generated using ligation-independent cloning [14]. An extended and updated protocol for ligation-independent cloning was recently published by Wendrich et al., 2015 [13]. Transcriptional fusions of the putative tagged genes as well as their neighboring genes can be generated in order to validate their expression pattern.

6. A complete protocol for sampling embryos for expression analysis can be found in Llavata Peris et al., 2013 [18].

7. At this point the collected plant material can be frozen at $-80^{\circ} \mathrm{C}$ and stored for later use.

8. The mixture will be divided into three phases: uppermost (watery) contains the DNA, middle (white) contains proteins and bottom (green) phase contains the rest.

9. Chloroform contamination affects subsequent enzymatic reaction. To avoid contamination, discard part of the aqueous phase (about $50 \mu \mathrm{l}$ ). 
10. For some samples the amplification with one/some of the AD primers could be unsuccessful. To increase the chance of amplification and recovery of the targeted TDNA flanking sequence, perform the TAIL-PCR using at least two different AD primers.

11. Higher $\mathrm{AD}$ primer concentration is required to guarantee abundant random priming and to increase the chance of an $\mathrm{AD}$ primer to bind nearby the insertion site.

12. The diluted products can be stored at $4^{\circ} \mathrm{C}$ up to 1 month.

13. This pair of primers should amplify DNA only in the absence of insertion. Use the primer that binds to the sequence in the proximity of left T-DNA border in combination with the third specific TAIL-PCR primers (SP3) in order to amplify DNA in presence of insertion.

\section{Acknowledgments}

This work was supported by grants from the Netherlands Organization for Scientific Research (ALW-NSFC Plant Development Collaborative Grant 846.11.001 to D.W.) and the European Research Council (Starting Grant CELL PATTERN; contract number 281573 to D.W.).

We would like to thank Jim Haseloff for generating the useful collection of GAL4/UAS enhancer trap lines.

\section{Figure Legends}




\section{Fig. 1 Schematic representation of TAIL-PCR.}

(a) Scheme of one side of the T-DNA insertion, indicated is the position of the three nested specific primers (SP1, SP2 and SP3 depicted on the T-DNA by black, pink and green arrow, respectively) and part of the target flanking sequence with the arbitrary degenerate (AD depicted by white arrow) primer. (b) Scheme of the three consecutive rounds of PCR and the expected TAIL-PCR products.

Fig. 2: Analysis of TAIL-PCR products from GAL4/UAS enhancer trap lines J0121, J3411, J2501 and RM1000.

(a) Agarose gel electrophoresis of secondary and tertiary PCR products with two different arbitrary primers. No products were obtained from line J3411 with AD2. Note the size shift of the tertiary TAIL-PCR products. Specific products excised from gel and used for sequencing are marked with red rectangle. M, marker; II, secondary TAIL-PCR products; III, tertiary TAIL-PCR products; AD2 and 3, arbitrary primers 2 and 3. (b) Nucleotide sequence of part of the T-DNA and flanking genomic region. The sequence shown in capital letters was retrieved by direct sequencing of the tertiary TAIL-PCR product of line RM1000. SP3 was exploited as sequencing primer.

\section{Fig. 3: Schematic representation of piece of DNA carrying GAL4/UAS T-DNA.}

Grey arrows indicate the neighboring genes. Primers used for genotyping are indicated as black and red arrows. Primers 1 and 3 will amplify the transgene, while primers 1 and 2 should amplify the wild type in absence of transgene. 
Table 1: Single reaction of Primary, Secondary and Tertiary TAIL-PCR

\begin{tabular}{lcccccc}
\hline & \multicolumn{2}{c}{ Primary TAIL-PCR } & \multicolumn{2}{c}{ Secondary TAIL-PCR } & \multicolumn{2}{c}{ Tertiary TAIL-PCR } \\
\cline { 2 - 6 } Reagents (stock solutions) & $\begin{array}{c}\text { Single } \\
\text { reaction }\end{array}$ & $\begin{array}{c}\text { Final } \\
\text { concentration }\end{array}$ & Single reaction & $\begin{array}{c}\text { Final } \\
\text { concentration }\end{array}$ & Single reaction & $\begin{array}{c}\text { Final } \\
\text { concentration }\end{array}$ \\
\hline DNA $(10-20 \mathrm{ng} / \mu \mathrm{l})$ & $4 \mu \mathrm{l}$ & $40-80 \mathrm{ng}$ & $\begin{array}{c}1 \mu \mathrm{l} 50 \mathrm{x} \text { diluted } \\
\text { primary product }\end{array}$ & & $\begin{array}{c}0.8 \mu \mathrm{l} 20 \mathrm{x} \text { diluted } \\
\text { secondary product }\end{array}$ \\
10x PCR Buffer & $2 \mu \mathrm{l}$ & $1 \mathrm{x}$ & $2 \mu \mathrm{l}$ & $1 \mathrm{x}$ & $4 \mu \mathrm{l}$ & $1 \mathrm{x}$ \\
dNTPs $(10 \mathrm{mM})$ & $0.4 \mu \mathrm{l}$ & $0.2 \mathrm{mM}$ & $0.4 \mu \mathrm{l}$ & $0.2 \mathrm{mM}$ & $1.6 \mu \mathrm{l}$ & $0.4 \mathrm{mM}$ \\
SP1 primer $(20 \mu \mathrm{M})$ & $0.4 \mu \mathrm{l}$ & $0.4 \mu \mathrm{M}$ & $0.4 \mu \mathrm{l}$ & $0.4 \mu \mathrm{M}$ & $1.2 \mu \mathrm{l}$ & $0.6 \mu \mathrm{M}$ \\
AD primer $(20 \mu \mathrm{M})$ & $4 \mu \mathrm{l}$ & $0.4 \mu \mathrm{M}$ & $4 \mu \mathrm{l}$ & $0.4 \mu \mathrm{M}$ & $8 \mu \mathrm{l}$ & $0.4 \mu \mathrm{M}$ \\
Taq Polymerase $(10 \mathrm{U} / \mu \mathrm{l})$ & $0.2 \mu \mathrm{l}$ & $2 \mathrm{U}$ & $0.2 \mu \mathrm{l}$ & $2 \mathrm{U}$ & $0.6 \mu \mathrm{l}$ & $6 \mathrm{U}$ \\
Milli-Q water & $9 \mu \mathrm{l}$ & & $12 \mu \mathrm{l}$ & & $23.8 \mu \mathrm{l}$ & $40 \mu \mathrm{l}$ \\
\hline Total volume & $20 \mu \mathrm{l}$ & & $20 \mu \mathrm{l}$ & & &
\end{tabular}


Table 2: Thermocycling conditions for TAIL-PCR

\begin{tabular}{|c|c|c|c|c|c|}
\hline \multicolumn{3}{|c|}{ Primary TAIL-PCR } & \multicolumn{3}{|c|}{ Secondary and Tertiary TAIL-PCR } \\
\hline $\begin{array}{l}\text { Step } \\
\text { number }\end{array}$ & $\begin{array}{c}\text { Temperature } \\
\left({ }^{\circ} \mathrm{C}\right)\end{array}$ & $\begin{array}{l}\text { Time } \\
\text { (min:s) }\end{array}$ & $\begin{array}{c}\text { Step } \\
\text { number }\end{array}$ & $\begin{array}{c}\text { Temperature } \\
\left({ }^{\circ} \mathrm{C}\right)\end{array}$ & $\begin{array}{l}\text { Time } \\
\text { (min:s) }\end{array}$ \\
\hline 1 & 93 & 01:00 & 1 & 93 & $00: 30$ \\
\hline 2 & 95 & 01:00 & 2 & 94 & $00: 10$ \\
\hline 3 & 80 & 01:00 & 3 & 64 & 01:00 \\
\hline 4 & 94 & $00: 30$ & 4 & 72 & 01:00 \\
\hline 5 & 58 & 01:00 & 5 & 94 & $00: 10$ \\
\hline 6 & 72 & 01:00 & 6 & 64 & 01:00 \\
\hline 7 & Go to Step 4 & 5 times & 7 & 72 & 01:00 \\
\hline 8 & 94 & $00: 30$ & 8 & 94 & 00:10 \\
\hline 9 & 25 & 03:00 & 9 & 44 & 01:00 \\
\hline 10 & 72 & 01:00 & 10 & 72 & 01:00 \\
\hline 11 & Ramp to 72 & $0.2^{\circ} \mathrm{C} / \mathrm{s}$ & 11 & Go to Step 2 & $\begin{array}{l}10 \\
\text { times }\end{array}$ \\
\hline 12 & 94 & $00: 10$ & 12 & 72 & 05:00 \\
\hline 13 & 64 & 01:00 & 13 & 4 & $\infty$ \\
\hline 14 & 72 & 01:00 & & & \\
\hline 15 & 94 & $00: 10$ & & & \\
\hline 16 & 64 & 01:00 & & & \\
\hline 17 & 72 & 01:00 & & & \\
\hline 18 & 94 & $00: 10$ & & & \\
\hline 19 & 44 & 01:00 & & & \\
\hline 20 & 72 & 01:00 & & & \\
\hline 21 & $\begin{array}{c}\text { Go to Step } \\
12\end{array}$ & $\begin{array}{l}15 \\
\text { times }\end{array}$ & & & \\
\hline 22 & 72 & 05:00 & & & \\
\hline 23 & 4 & $\infty$ & & & \\
\hline
\end{tabular}




\section{References}

1. Levesque MP, Vernoux T, Busch W, Cui H, Wang JY, Blilou I, Hassan H, Nakajima K, Matsumoto N, Lohmann JU, Scheres B, Benfey PN (2006) Whole-Genome Analysis of the SHORT-ROOT Developmental Pathway in $<$ italic>Arabidopsis</italic>. PLoS Biol 4 (5):e143. doi:10.1371/journal.pbio.0040143

2. De Rybel B, Moller B, Yoshida S, Grabowicz I, Barbier de Reuille P, Boeren S, Smith RS, Borst JW, Weijers D (2013) A bHLH complex controls embryonic vascular tissue establishment and indeterminate growth in Arabidopsis. Dev Cell 24 (4):426-437. doi:10.1016/j.devcel.2012.12.013 3. Fendrych $M$, Van Hautegem $T$, Van Durme $M$, Olvera-Carrillo $Y$, Huysmans $M$, Karimi $M$, Lippens S, Guérin Christopher J, Krebs M, Schumacher K, Nowack Moritz K (2014) Programmed Cell Death Controlled by ANAC033/SOMBRERO Determines Root Cap Organ Size in <em>Arabidopsis</em>. Current Biology 24 (9):931-940. doi:10.1016/j.cub.2014.03.025 4. Sena G, Wang X, Liu H-Y, Hofhuis H, Birnbaum KD (2009) Organ regeneration does not require a functional stem cell niche in plants. Nature 457 (7233):1150-1153. doi:http://www.nature.com/nature/journal/v457/n7233/suppinfo/nature07597 S1.html

5. Sugimoto K, Jiao Y, Meyerowitz EM (2010) Arabidopsis Regeneration from Multiple Tissues Occurs via a Root Development Pathway. Dev Cell 18 (3):463-471. doi:10.1016/j.devcel.2010.02.004

6. Rademacher EH, Lokerse AS, Schlereth A, Llavata-Peris Cl, Bayer M, Kientz M, Freire Rios A, Borst JW, Lukowitz W, Jurgens G, Weijers D (2012) Different auxin response machineries control distinct cell fates in the early plant embryo. Dev Cell 22 (1):211-222. doi:10.1016/j.devcel.2011.10.026

7. Haseloff J (1999) GFP variants for multispectral imaging of living cells. Methods Cell Biol 58:139151

8. Weijers D, Schlereth A, Ehrismann JS, Schwank G, Kientz M, Jurgens G (2006) Auxin triggers transient local signaling for cell specification in Arabidopsis embryogenesis. Dev Cell 10 (2):265270. doi:10.1016/j.devcel.2005.12.001

9. Kang YH, Song S-K, Schiefelbein J, Lee MM (2013) Nuclear Trapping Controls the PositionDependent Localization of CAPRICE in the Root Epidermis of Arabidopsis. Plant Physiol 163 (1):193-204

10. Schlereth A, Moller B, Liu W, Kientz M, Flipse J, Rademacher EH, Schmid M, Jurgens G, Weijers $D$ (2010) MONOPTEROS controls embryonic root initiation by regulating a mobile transcription factor. Nature 464 (7290):913-916. doi:10.1038/nature08836

11. Radoeva T, ten Hove CA, Saiga S, Weijers D (2016) Molecular Characterization of Arabidopsis GAL4/UAS Enhancer Trap Lines Identifies Novel Cell-Type-Specific Promoters. Plant Physiol 171 (2):1169-1181. doi:10.1104/pp.16.00213

12. Palovaara J, de Zeeuw T, Weijers D (2016) Tissue and Organ Initiation in the Plant Embryo: A First Time for Everything. Annu Rev Cell Dev Biol 32 (1):47-75. doi:10.1146/annurev-cellbio111315-124929

13. Wendrich JR, Liao CY, van den Berg WA, De Rybel B, Weijers D (2015) Ligation-independent cloning for plant research. Methods Mol Biol 1284:421-431. doi:10.1007/978-1-4939-2444-8_21 
14. De Rybel $B$, van den Berg W, Lokerse A, Liao CY, van Mourik $H$, Moller B, Peris CL, Weijers $D$ (2011) A versatile set of ligation-independent cloning vectors for functional studies in plants. Plant Physiol 156 (3):1292-1299. doi:10.1104/pp.111.177337

15. Liu YG, Mitsukawa N, Oosumi T, Whittier RF (1995) Efficient isolation and mapping of Arabidopsis thaliana T-DNA insert junctions by thermal asymmetric interlaced PCR. Plant $\mathrm{J} 8$ (3):457-463

16. Liu YG, Chen Y (2007) High-efficiency thermal asymmetric interlaced PCR for amplification of unknown flanking sequences. Biotechniques 43(5):649-650

17. Liu YG, Whittier RF (1995) Thermal asymmetric interlaced PCR: automatable amplification and sequencing of insert end fragments from P1 and YAC clones for chromosome walking. Genomics 25(3)::674-681

18. Llavata-Peris C, Lokerse A, Moller B, De Rybel B, Weijers D (2013) Imaging of phenotypes, gene expression, and protein localization during embryonic root formation in Arabidopsis. Methods Mol Biol 959:137-148. doi:10.1007/978-1-62703-221-6_8 